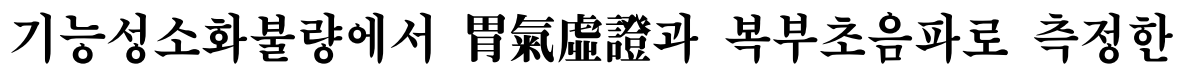 위 배출능과의 상관성 분석
}

남성욱, 박재우, 김진성

경희대학교 대학원 임상한의학과

\section{Correlation Analysis Between Stomach Qi Deficiency Pattern and Gastric Emptying Measured by Abdominal Ultrasonography in Patients with Functional Dyspepsia}

\author{
Seong-uk Nam, Jae-woo Park, Jin-sung Kim \\ Dept. of Clinical Korean Medicine, Graduate School, Kyung Hee University
}

\begin{abstract}
Objective: The purpose of this study was to analyze the correlation between Stomach Qi Deficiency and gastric emptying as measured by abdominal ultrasonography in postprandial distress syndrome (PDS), a subgroup of functional dyspepsia (FD).

Methods: Ten patients who met the RomeII diagnostic criteria for PDS and ten healthy controls participated in this study Gastric emptying shown as the half-life of gastric volume $\left(T_{1 / 2}\right)$ was measured by abdominal ultrasonography. The degree of Stomach Qi Deficiency was assessed using the scale for Stomach Qi Deficiency pattern (SSQD). In addition. functional dyspepsia-related quality of life (FD-QoL), Nepean dyspepsia index-Korean version (NDI-K), and visual analogue scale (VAS) of distention and fullness were conducted on all subjects.

Results: The scores of SSQD, FD-QoL, NDI-K, and VAS of distention and fullness in the patient group were significantly higher than those in the control group $(\mathrm{p}<0.05)$. $T_{1 / 2}$ was also higher in the patient group than in the control group. The SSQD score significantly correlated positively with $T_{1 / 2}$ in the patient group $(r=0.640, p=0.046)$. However, there was no significant correlation between $T_{1 / 2}$ and other questionnaire scores in the patient group.

Conclusions: Our results suggest that the gastric emptying measured by abdominal ultrasonography could be a quantitative indicator to diagnose Stomach Qi Deficiency in FD patients, especially the PDS subtype.
\end{abstract}

Key words: functional dyspepsia, postprandial distress syndrome, stomach Qi deficiency, gastric emptying, abdominal ultrasonography

\section{I. 서 론}

기능성소화불량(functional dyspepsia, FD)은 인

- 투고일 : 2018.05.21, 심사일: 2018.06.30, 게재확정일: 2018.06.29

· 교신저자: 김진성 서울시 동대문구 경희대로 23

경희대학교한방병원 위장소화내과

TEL: 02-958-8895

E-mail: oridoc@khu.ac.kr

- 본 논문은 제 1저자의 2018년도 경희대학교 일반대학원 임상 한의학과 석사학위 논문을 수정, 보완한 것임.
과관계가 명확한 기질적 질환 없이 상복부에 다양 한 위장관 증상이 나타나는 질환이다 ${ }^{1}$. 전 세계적 이환율은 5\% 11\%이고 ${ }^{2}$, 우리나라의 경우는 $7.7 \%$ 로 $^{3}$ 보고되었다. 이는 직접적으로 생명을 위협하는 질환은 아니지만, 환자 개인에게는 삶의 질을 저하 시키고 사회적으로도 의료비용의 규모가 꾸준히 증 가하고 있는 실정이다 ${ }^{4}$.

기능성소화불량의 병태생리는 아직까지 명확히 밝혀진 바 없으나, 위 배출 지연, 내장과민성, 정신 
질환 및 스트레스 등이 관여 하는 것으로 알려져 있으며, 그 중 위 배출 장애는 기능성소화불량 환 자 중 $40 \%$ 에서 나타난다고 보고된 바 있다.

기능성소화불량에는 식후불편감증후군(postprandial distress syndrome, PDS)과 상복부통증증후군(epigastric pain syndrome, EPS)의 두 가지 아형으로 분류될 수 있다. 그 중 $\mathrm{PDS}$ 는 조기 만복감과 식후 포만감을 호소하는 유형으로, 병태생리학적으로 위 배출 장애 와 관련이 있는 것으로 나타났다. 한의학적으로는 상복부가 막혀 답답하고 만져도 형체나 통증이 없 는 비만(㾂滿)의 범주에 포함되는 것으로 볼 수 있 다. 이처럼 위장의 운동성 장애는 기능성소화불량 의 중요한 기전이며, 이를 반영하는 위 배출능의 평가는 특히, PDS 유형에서 큰 의미가 있다.

위 배출능을 평가하는 방법으로는 바륨을 이용 한 X-ray 검사 ${ }^{8}$, 삽관법 ${ }^{9}$, 무선운동캡슐검사(wireless motility capsule test) $)^{10}$, 위배출호기검사(gastric emptying breath test, $\mathrm{GEBT})^{10}$, 자기공명영상(magnetic resonance imagine, MRI $)^{10}$ 등이 있으나 여러 한계점들로 인해 잘 시행되지 않고 있으며, 위 배출능 평가의 표준 금 본위 검사(gold standard test)인 신티그래피(scintigraphy) ${ }^{11}$ 는 방사성 동위원소의 노출로 인해 환자가 거부감 을 일으킬 수 있다는 단점이 있다 ${ }^{12}$. 이와 달리, 초 음파 검사는 비침습적이고 비용이 저렴하며 편리 하고 방사선 노출의 위험이 없다는 장점이 있다 ${ }^{13}$. 이와 같은 초음파를 이용한 위 배출능 측정에 대 한 국내외의 선행연구 ${ }^{1214.15}$ 를 바탕으로 백 등 ${ }^{16}$ 은 기능성소화불량 환자를 대상으로 비기허증(脾氣虛 證)과 위 배출능 사이의 상관성을 분석한 연구를 진행하였다.

한편, 한의학에서 소화기능을 다스리는 장기는 비위(脾胃)로 그 중 위의 기능을 의미하는 위기 (胃氣)는 수곡(水穀)으로부터 발생하는 정기(正氣) 를 만드는 근본이 되며, 광의의 위기(胃氣)는 소화 기능 전체를 아우르는 기능을 의미하게 된다 ${ }^{17}$. 이 러한 위기(胃氣)가 부족한 상황인 위기허증(胃氣 虛證)은 식후 위완비만(胃脘㿋滿)하는 특징이 있
으며 소화기 증상뿐만 아니라 허증(虛登)과 관련 한 전신적인 증상까지 나타나는 증후로 ${ }^{18}$, 이는 기 능성소화불량의 증상적 특징과 유사하며 특히 PDS 유형과 밀접한 관련이 있다.

이를 바탕으로 최근 개발된 위기허증 변증설문지 (scale for Stomach Qi Deficiency pattern, SSQD) 를 한방 변증의 진단 지표로 삼았다. 그 외에 비교 기준이 될 만한 평가 척도로 기능성소화불량 환자 에게 많이 시행되고 있는 기능성소화불량 삶의 질 척도(Functional dyspepsia related quality of life, FD-QoL), 한국판 Nepean 소화불량증 척도(Nepean dyspepsia index-Korean version, NDI-K)를 채택 하였으며, 또한 한의학에서 비만(痞滿)의 증상이 $\mathrm{PDS}$ 유형의 증상과 유사하므로 비만(㾂滿)의 시 각적 상사 척도(Visual analogue scale, VAS)도 비 교 기준으로 함께 시행하였다.

이미 백 등 $^{16}$ 이 비기허증(脾氣虛證)과 위 배출능 의 상관성에 대한 연구를 진행한 바 있으나, 위에 서 언급하였듯 위기허증(胃氣虛證)이 기능성소화 불량 중 $\mathrm{PDS}$ 유형과의 증상적 연관성이 더 높다. 또한 한의학에 기초하여 초음파 검사를 활용하기 위해서는, 해당 질환과 관련성 높은 변증유형과의 상관성을 밝혀 한의학 진단의 한 방법으로 초음파 를 활용할 과학적 근거를 마련하는 것이 필요하다.

이에 본 연구에서는 복부초음파를 통해 측정한 위 배출능의 한의학적 활용성을 확인해 보기 위해, 기능성소화불량 환자들 중에서 로마기준 III에 따 라 $\mathrm{PDS}$ 유형으로 진단된 환자군 10 명과 건강인 대조군 10 명을 대상으로 복부초음파를 이용하여 위 배출능(gastric emptying)을 측정하고 앞서 언 급한 4 가지 지표의 설문지 점수와의 상관성에 대 해 분석하였다.

\section{II. 대상 및 방법}

1. 연구대상

본 연구는 2017년 5월부터 2017년 11월까지 경희 
대학교 한방병원 위장소화내과에서 진행되었으며, 지원자들 중 기능성소화불량 환자군(이하 환자군)과 기능성소화불량으로 진단되지 않는 건강인 대조군 (이하 대조군) 각각 10 명씩 총 20명을 모집하였다. 특히, 환자군은 포함기준 및 제외기준을 적용하여 모집하였다(Table 1). 연구대상자 전원은 연구 목 적과 방법 등에 대해 연구자로부터 충분한 설명을
들은 뒤 자발적인 동의서를 작성하고 연구에 참여 하였다. 본 연구는 의학연구윤리에 대한 헬싱키 선 언을 준수하였으며, 경희대학교 부속 한방병원 임 상시험윤리위원회(institutional review board, IRB) 의 승인을 받은 후 진행되었다(IRB No. KOMCIRB -170317-HR-006-03).

Table 1. Inclusion and Exclusion Criteria in Patient Group

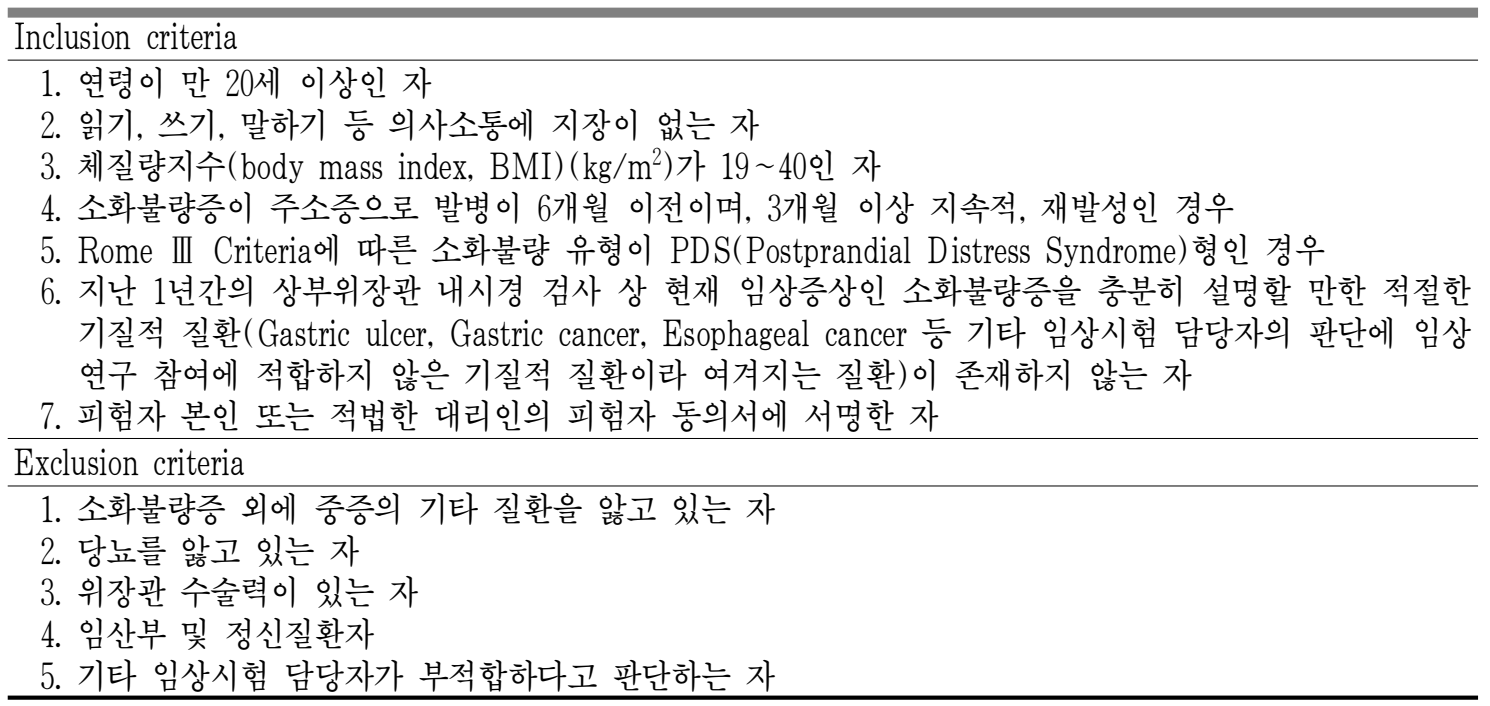

\section{2. 연구방법}

\section{1) 인구학적 조사}

전체 연구대상자 20명에게 설문지 및 면담을 통 해 연령 (년), 성별, 신장 $(\mathrm{cm})$, 체중 $(\mathrm{kg})$, 체질량지 수(body mass index, BMI) $\left(\mathrm{kg} / \mathrm{m}^{2}\right.$ ), 이환기간(개 월), 과거력 및 현병력, 수술력, 약물 사용력, 음주 력, 흡연력 등을 조사하였다.

2) 기능성소화불량의 진단 및 유형 분류

전문가 1 인이 문진을 통해 로마기준 III를 적용 하여 연구대상자들 중 기능성소화불량의 PDS 유 형에 해당하는 대상자들만 환자군에 포함하였다 (Table 2). 2006년 개정된 로마기준 III에 따르면,
기능성소화불량은 진단시점으로부터 적어도 6 개월 전에 발생하여 지난 3 개월간 지속되는 만성적인 소화불량 증상이 있으며, 상부 위장관 내시경검사 등으로 증상을 설명할 수 있는 기질적 질환이나 대사성 및 전신적 원인이 없는 경우로 진단한다. 그 중 조기 만복감 및 식후 포만감을 호소하는 환 자는 식후불편감증후군인 $\mathrm{PDS}$ 유형으로 본 연구 에 포함시켰으며, 상복부 쓰림 및 통증을 주로 호 소하는 환자는 상복부통증증후군인 $\mathrm{EPS}$ 유형은 본 연구에서 제외시켰다. 대조군의 경우 기능성소 화불량을 않고 있지 않으므로 유형 분류를 시행하 지 않았다. 
Table 2. Rome III Diagnostic Criteria for Functional Dyspepsia, 2006 19

\begin{tabular}{l} 
Rome III diagnostic criteria for functional dyspepsia \\
At least 3 months, with onset at least 6 months previously, of one or more of the following : \\
1. bothersome postprandial fullness \\
2. early satiation \\
3. epigastric pain \\
4. epigastric burning \\
AND \\
no evidence of structural disease (including upper endoscopy) that is likely to explain the symptoms \\
Rome III diagnostic criteria for epigastric pain syndrome (EPS) \\
At least 3 months, with onset at least 6 months previously, with ALL of the following symptoms : \\
1. Pain or burning localized to the epigastrium of at least moderate severity, at least once per week \\
2. Pain is intermittent \\
3. Pain is not generalized or localized to other abdominal or chest regions \\
4. Pain is not relieved by defecation or passage of flatus \\
5. Pain does not fulfill criteria for gallbladder or sphincter of Oddi disorders \\
Supportive criteria \\
1. Pain may be of a burning quality, but without a retrosternal component. \\
2. Pain is commonly induced or relieved by ingestion of a meal, but may occur while fasting. \\
3. Pain may coexist with postprandial distress syndrome. \\
Rome III diagnostic criteria for postprandial distress syndrome (PDS) \\
\hline At least 3 months, with onset at least 6 months previously, with one or both of the following symptoms : \\
1. Bothersome postprandial fullness, occurring after ordinary-sized meals at least several times per week \\
2. Early satiation that prevents finishing a regular meal, at least several times per week \\
Supportive criteria \\
1. Upper abdominal bloating or postprandial nausea or excessive belching can be present \\
2. May coexist with epigastric pain syndrome \\
\hline
\end{tabular}

3) 복부초음파 검사를 통한 위 배출능 측정 복부초음파 검사를 통해 위 배출능을 평가하기 위한 지표로 위배출반감기(half-life of gastric volume, 이하 $T_{1 / 2}$ )를 사용하였다. $T_{1 / 2}$ 를 구하기 위해서는 먼저 위 전체 용적을 알아야하므로 위 전정부의 단 면적(cross-sectional area of antrum, CSA)을 통해 위 전체 용적을 구할 수 있다는 선행연구 ${ }^{20}$ 의 방법을 이용하였다. 검사에 사용한 초음파기기는 $\mathrm{LOGIQ}$ P5(GE Medical Systems, USA)이며, 4C Convex probe를 사용하였다. 연구대상자는 우측 측와위 자 세로 눕고, 검사자는 탐색자를 시상면(sagittal plane) 으로 하여(Fig. 1) 촬영하였다. 이 때, 초음파 영상 에서 위 전정부의 횡단면이 원형이나 타원형 모양
이 나오도록(Fig. 2) 탐색자의 기울기를 조정하였 다. 이렇게 촬영된 영상에서 횡단면의 단면적을 구 하였으며 공식 ${ }^{21}$ 은 다음과 같다.

$\mathrm{CSA}\left(\mathrm{cm}^{2}\right)=(\mathrm{AP}(\mathrm{cm}) \times \mathrm{CC}(\mathrm{cm}) \times \pi) / 4$

(AP : Antero-Posterior diameter, CC : Cranio Caudal diameter)

위 공식에서 산출된 위 전정부의 단면적 값을 이용하여 위 전체 용적을 계산하였으며 공식 ${ }^{22}$ 은 다 음과 같다.

$\mathrm{GV}(\mathrm{ml})=27.0+14.6 \times$ right-lat $\mathrm{CSA}\left(\mathrm{cm}^{2}\right)-1.28 \times$ age $(\mathrm{yr})$

(GV : Gastric Volume)

위 공식을 적용하기 위해서 연구대상자의 체질 량지수 $(\mathrm{BMI})\left(\mathrm{kg} / \mathrm{m}^{2}\right)$ 는 $19 \sim 40$ 이어야 하며, 임신 중 
이 아닌 18 85세의 성인이어야 한다. 또한 앞서 언 급하였듯이 측정 시 대상자의 체위는 우측 측와위 를 유지해야 한다 ${ }^{22}$.

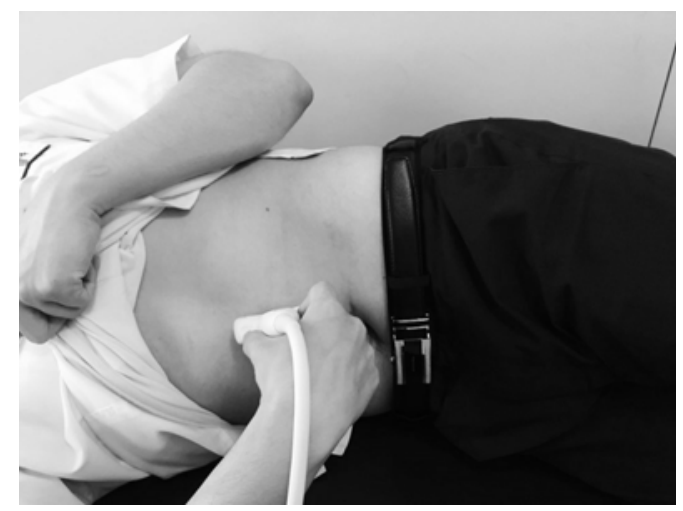

Fig. 1. The position of subjects and the ultrasonic probe to obtain the cross-sectional area (CSA) of gastric antrum.

All subjects are needed to be in a right lateral decubitus position. The probe must be in a sagittal plane.

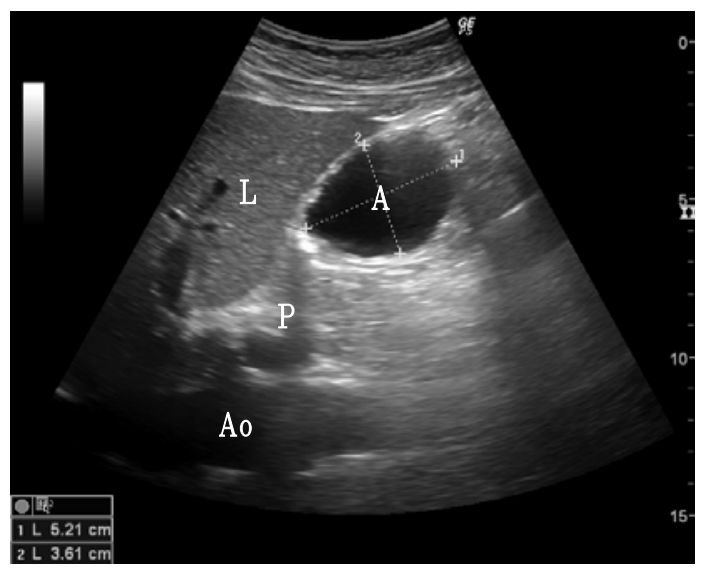

Fig. 2. Ultrasound image of cross-sectional area (CSA) of gastric antrum in sagittal view.

This image was taken after ingesting $500 \mathrm{ml}$ orange juice. A : antrum, L : liver, P : pancreas, Ao : aorta

연구대상자는 검사 전에 몇 가지 주의사항을 지
켜야하는데, 검사 전 최소 3 일간은 위장관 운동에 관련된 약물의 복용을 금해야하고 여성의 경우 월경 전후 일주일 안에는 검사를 금하며 흡연자의 경우 초음파 시행 하루 전부터 금연을 해야 하고 검사 전 최소 8 시간 이상 금식을 시행해야 한다 ${ }^{14}$.

초음파 검사는 공복 시 1 회 시행하였고, 오렌지 주스 $(500 \mathrm{ml}, 225 \mathrm{kcal})$ 를 복용한 후 최대로 확장된 시점에 측정한 후, 그 때의 시간을 주스를 복용한 시점으로부터 몇 분 후인지를 기록하였다. 이후 주 스를 복용한 시점으로부터 처음 1 시간 동안은 15 분 간격(주스 복용 시점으로부터 15분 후, 30 분 후, 45 분 후, 60 분 후)으로, 이후 1 시간 동안은 30 분 간격 (주스 복용 시점으로부터 90분 후, 120 분 후)으로 시행하였다. 검사와 검사 사이 남는 시간에는 편안 한 자세로 앉아서 대기하도록 하였다.

복부 초음파를 이용하여 해당시간에 검사를 시 행할 때마다 위 용적을 측정하였다. 구체적으로는 백 등 ${ }^{16}$ 의 연구방법을 참고하여 공복 시의 위 용적 을 측정하고 식후 최대 확장 시의 위 용적을 측정 하여 위 용적 확장율과 최대 확장 시 걸리는 시간 을 구하였고, 각각 측정한 값을 통해 위 용적이 식 후 최대 확장 시의 위용적과 공복 시의 위용적의 차이의 절반으로 줄어드는 시점인 반감기 $\left(T_{1 / 2}\right)$ 를 측정하였다.

4) 위기허증 변증설문지(SSQD)

본 연구에서 사용한 위기허증 변증설문지 (scale for Stomach Qi Deficiency pattern, SSQD)는 위기 허증 여부를 진단하기 위해 개발된 설문지이다(Table 3). 이는 최근 이 ${ }^{23}$ 가 제작한 설문지로 주된 문항구 성은 위기허증 고유요인(문항번호 $1,4,9,10,11,12$ ), 식사요인(문항번호 $2,5,8$ ), 허증요인(문항번호 3 , $6,7)$ 으로 이루어져 있다. 12 가지 항목에 대하여 각 각 심한 정도에 따라 0점에서 4점까지 5단계로 평 가하였다 $(0=$ 전혀 그렇지 않다, $1=$ 별로 그렇지 않 다, $2=$ 중간 정도 그렇다, $3=$ 자주 그렇다, $4=$ 매우 그렇다).

총 12 개의 문항 중 9 개의 문항은 연구대상자가 
직접 기입하였고, 3 개의 문항(腹診, 舌診, 脈診)은 한의사가 연구대상자를 진찰한 후 중증도를 평가 하도록 하였다. 각 문항에 대한 응답점수를 합산하 여 최종 점수를 구한 후 최적절삭점인 14점을 기준
으로 하여, 이를 초과한 경우에는 위기허증으로 진 단하고, 이하인 경우에는 위기허증이 아닌 것으로 진단하였다 ${ }^{23}$.

Table 3. Scale for Stomach Qi Deficiency Pattern (SSQD)

\section{위기허증 진단평가도구(scale for Stomach Qi Deficiency pattern, SSQD)}

문항

질 문

전혀

그렇지

않다(0)

별로

그렇지

않다(1)

중간 정도 자주

매우 그렇다(2) 그렇다(3)

심하거나

항상

그렇다(4)

\begin{tabular}{|c|c|c|c|c|c|c|}
\hline 1 & 윗배가 항상 답답하고 식후 더 불편하다. & $\square 0$ & $\square_{1}$ & $\square_{2}$ & $\square_{3}$ & $\square_{4}$ \\
\hline 2 & 음식 생각이 안나 식욕이 없다. & $\square_{0}$ & $\square_{1}$ & $\square_{2}$ & $\square 3$ & $\square_{4}$ \\
\hline 3 & 몸이 나른하고 힘이 없다. & $\square_{0}$ & $\square_{1}$ & $\square_{2}$ & $\square_{3}$ & $\square_{4}$ \\
\hline 4 & $\begin{array}{l}\text { 윗배가 은은하게 아프나 심하지 않아 따 } \\
\text { 뜻이 해주면 줄어든다. }\end{array}$ & $\square 0$ & $\square_{1}$ & $\square 2$ & $\square 3$ & $\square_{4}$ \\
\hline 5 & 트림이 자주 나온다. & $\square_{0}$ & $\square_{1}$ & $\square 2$ & $\square 3$ & $\square 4$ \\
\hline 6 & 정신적으로 쉽게 피로하다. & $\square 0$ & $\square_{1}$ & $\square_{2}$ & $\square_{3}$ & $\square_{4}$ \\
\hline 7 & $\begin{array}{l}\text { 얼굴이 윤기 없이 누렇게 떠 있거나 핏기 } \\
\text { 가 없다. }\end{array}$ & $\square 0$ & $\square_{1}$ & $\square 2$ & $\square 3$ & $\square 4$ \\
\hline 8 & 입안이 덤덤해서 음식맛을 모른다. & $\square_{0}$ & $\square_{1}$ & $\square_{2}$ & $\square_{3}$ & $\square_{4}$ \\
\hline 9 & 증상이 언제부터 시작되었습니까? & 발병일 & & & & \\
\hline \multicolumn{7}{|c|}{ 아래 항목은 한의사의 진찰에 따라 작성하게 됩니다. } \\
\hline & $\begin{array}{r}1 \text { 주 이 } \\
\text { 이내 } \square_{0} \text { 개월 미 }\end{array}$ & & $\begin{array}{c}\text { 1개월 이상 } \\
\text { 3개월 미만 } \square_{2}\end{array}$ & $\begin{array}{l}\text { 3개월 이상 } \\
6 \text { 개월 미만 }\end{array}$ & 6개월 & 이상 $\square_{4}$ \\
\hline
\end{tabular}

문항

질문

전혀

그렇지

않다(0)
별로

그렇지 않다(1)
중간 정도 자주

그렇다(2) 그렇다(3) 그렇다(4)

\begin{tabular}{|c|c|c|c|c|c|}
\hline 10 한의사의 복진소견 ${ }^{1)}$ & $\square 0$ & $\square_{1}$ & $\square_{2}$ & $\square_{3}$ & $\square_{4}$ \\
\hline 11 한의사 맥진소견 ${ }^{2)}$ & $\square_{0}$ & $\square_{1}$ & $\square_{2}$ & $\square_{3}$ & $\square_{4}$ \\
\hline 12 한의사 설진소견 ${ }^{3)}$ & $\square_{0}$ & $\square_{1}$ & $\square_{2}$ & $\square_{3}$ & $\square_{4}$ \\
\hline
\end{tabular}

1) 복진상 心下㾂, 心下軟, 漉漉有聲이 있을시 심한 정도에 따라 한의사의 평가

2) 우관맥에 대한 맥진상 脈微弱에 대한 한의사의 평가

3) 설진상 舌淡苔少에 대한 한의사의 평가

- 위기허증 진단을 위한 최적 절단점 14 점 초과인 경우

위기허증으로 진단하고, 이하인 경우 위기허증이 아닌 것으로 진단한다. 
5) 기능성소화불량 삶의 질 설문지 (FD-QoL)

연구대상자들의 삶의 질을 평가하고자 기능성소 화불량 삶의 질 설문지(Functional dyspepsia related quality of life, FD-QoL)를 작성하도록 하였다. FD-QoL은 우리나라 환자를 대상으로 개발되어 타 당도와 신뢰도가 검증된 삶의 질 평가도구이다 ${ }^{24}$.

FD-QoL은 4가지 영역으로 구성되어 있는데, 섭 식에 관한 질문 5 개 문항, 생활 활력에 관한 질문 4 개 문항, 정서에 관한 질문 6 개 문항, 사회적 기능
에 관한 질문 5 개 문항으로, 각 문항을 5 단계로 평 가한다 $(0=$ 전혀 그렇지 않다, $1=$ 조금 그렇다, $2=$ 중간 정도 그렇다. $3=$ 많이 그렇다, $4=$ 매우 그렇 다). 본 연구에서는 4 가지 영역의 각 점수를 합산 하여 총점으로 연구대상자들의 삶의 질 수준을 평 가하였다(Table 4). FD-QoL의 합계 점수가 높을 수록 삶의 질 수준은 저하되어 있는 것으로 평가 하였다.

Table 4. Functional Dyspepsia Related Quality of Life (FD-QoL)

FD-QoL (Functional Dyspepsia related quality of Life)

아래 문항은 기능성소화불량이 귀하의 삶의 질에 어떤 영향을 미치는지 조사하기 위한 것입니다. 왼쪽의 각 문항에 대해 지난 2주 동안 귀하가 어느 정도로 경험하였는지 가장 가깝게 생각되는 점수를 하나 골라 그 번호에 체크 $(\bar{\checkmark})$ 표시를 하십시오.

1. 섭식에 대한 질문

\begin{tabular}{|c|c|c|c|c|c|}
\hline 문 항 & $\begin{array}{c}\text { 전혀 } \\
\text { 그렇지 않다 }\end{array}$ & $\begin{array}{l}\text { 조금 } \\
\text { 그렇다 }\end{array}$ & $\begin{array}{c}\text { 중간 정도 } \\
\text { 그렇다 }\end{array}$ & $\begin{array}{c}\text { 많이 } \\
\text { 그렇다 }\end{array}$ & $\begin{array}{c}\text { 매우 많이 } \\
\text { 그렇다 }\end{array}$ \\
\hline 1. 다른 사람들처럼 먹고 마시는 것이 힘들었다. & $\square_{0}$ & $\square_{1}$ & $\square_{2}$ & $\square_{3}$ & $\square_{4}$ \\
\hline 2. 음식을 마음대로 먹을 수 없었다. & $\square_{0}$ & $\square_{1}$ & $\square_{2}$ & $\square_{3}$ & $\square_{4}$ \\
\hline 3. 소량씩 주의해서 먹어야 했다. & $\square_{0}$ & $\square_{1}$ & $\square_{2}$ & $\square_{3}$ & $\square_{4}$ \\
\hline 4. 식사하는 것이 즐겁지 않았다. & $\square_{0}$ & $\square_{1}$ & $\square_{2}$ & $\square_{3}$ & $\square_{4}$ \\
\hline 5. 음식 섭취에 과민하였다. & $\square_{0}$ & $\square_{1}$ & $\square_{2}$ & $\square_{3}$ & $\square_{4}$ \\
\hline
\end{tabular}

2. 생활 활력에 관한 질문

\begin{tabular}{lcccccc}
\hline & 문 항 & $\begin{array}{c}\text { 전혀 } \\
\text { 그렇지 않다 }\end{array}$ & $\begin{array}{c}\text { 조금 } \\
\text { 그렇다 }\end{array}$ & $\begin{array}{c}\text { 중간 정도 } \\
\text { 그렇다 }\end{array}$ & $\begin{array}{c}\text { 많이 } \\
\text { 그렇다 }\end{array}$ & $\begin{array}{c}\text { 매우 많이 } \\
\text { 그렇다 }\end{array}$ \\
\hline 1. 기운이 없었다. & $\square_{0}$ & $\square_{1}$ & $\square_{2}$ & $\square_{3}$ & $\square_{4}$ \\
\hline 2. 피로했다. & $\square_{0}$ & $\square_{1}$ & $\square_{2}$ & $\square_{3}$ & $\square_{4}$ \\
\hline 3. 자꾸 눕고 싶었다. & $\square_{0}$ & $\square_{1}$ & $\square_{2}$ & $\square_{3}$ & $\square$ \\
\hline 4. 낮에 졸렸다. & $\square_{0}$ & $\square_{1}$ & $\square_{2}$ & $\square_{3}$ & $\square$ \\
\hline
\end{tabular}

3. 정서에 관한 질문

문 항

1. 좌절감을 느꼈다.
전혀 조금 중간 정도 많이 매우 많이 그렇지 않다 그렇다 그렇다 그렇다 그렇다 


\begin{tabular}{lccccc}
\hline 2. 우울했다. & $\square_{0}$ & $\square_{1}$ & $\square_{2}$ & $\square_{3}$ & $\square_{4}$ \\
\hline 3. 짜증이 났다. & $\square_{0}$ & $\square_{1}$ & $\square_{2}$ & $\square_{3}$ & $\square_{4}$ \\
\hline 4. 불안했다. & $\square_{0}$ & $\square_{1}$ & $\square_{2}$ & $\square_{3}$ & $\square_{4}$ \\
\hline 5. 어두운 터널 안에 있는 것 같이 느껴졌다. & $\square_{0}$ & $\square_{1}$ & $\square_{2}$ & $\square_{3}$ & $\square_{4}$ \\
\hline 6. 병이 심각해질까봐 두려웠다. & $\square_{0}$ & $\square_{1}$ & $\square_{2}$ & $\square_{3}$ & $\square$ \\
\hline
\end{tabular}

4. 사회적 기능에 관한 질문

\begin{tabular}{|c|c|c|c|c|c|}
\hline 문 항 & $\begin{array}{c}\text { 전혀 } \\
\text { 그렇지 않다 }\end{array}$ & $\begin{array}{l}\text { 조금 } \\
\text { 그렇다 }\end{array}$ & $\begin{array}{l}\text { 중간 정도 } \\
\text { 그렇다 }\end{array}$ & $\begin{array}{l}\text { 많이 } \\
\text { 그렇다 }\end{array}$ & $\begin{array}{l}\text { 매우 많이 } \\
\text { 그렇다 }\end{array}$ \\
\hline 1. 일(직장 또는 학교 일)을 잘 할 수 없었다. & $\square 0$ & $\square_{1}$ & $\square 2$ & $\square_{3}$ & $\square 4$ \\
\hline 2. 내가 좋아하는 취미 또는 여가를 잘 할 수 없었다. & $\square_{0}$ & $\square_{1}$ & $\square_{2}$ & $\square_{3}$ & $\square_{4}$ \\
\hline 3. 남들(친구 또는 동료)과 어울리기 어려웠다. & $\square_{0}$ & $\square_{1}$ & $\square_{2}$ & $\square_{3}$ & $\square_{4}$ \\
\hline 4. 가족 / 친지들과 어울리기 어려웠다. & $\square_{0}$ & $\square_{1}$ & $\square_{2}$ & $\square_{3}$ & $\square_{4}$ \\
\hline $\begin{array}{l}\text { 5. 성취하고자 하는 목적을 달성하기 위해 노력하기 } \\
\text { 싫었다. }\end{array}$ & $\square_{0}$ & $\square_{1}$ & $\square_{2}$ & $\square_{3}$ & $\square_{4}$ \\
\hline 6. 내 자신이 무기력하게 느껴졌다. & $\square_{0}$ & $\square_{1}$ & $\square_{2}$ & $\square_{3}$ & $\square_{4}$ \\
\hline
\end{tabular}

6) 한국판 Nepean 소화불량증 설문지 (NDI-K) 연구대상자들의 소화불량 상태를 평가하고자 한 국판 Nepean 소화불량증 설문지 (Nepean dyspepsia index-Korean version, NDI-K)를 작성하도록 하였 다. Nepean 소화불량증 설문지(Nepean dyspepsia index, NDI)는 Talley 등 ${ }^{25}$ 이 개발한 설문지로 증 상 및 삶의 질을 평가하는 도구이다. 이를 국내에 서 이용하기 위해 한국판으로 번역한 것이 NDI-K 로, 원저자의 승인을 받아 번역과 역번역을 거쳐 완성되었다. 본 설문지는 검사-재검사의 신뢰도가 높고, 공존 타당도, 변별 타당도, 내적 일치도, 구성 타당도 등이 검증된 설문지이다 ${ }^{26} . \mathrm{NDI}-\mathrm{K}$ 는 증상 점수표, 삶의 질에 관한 문항, 가중치에 대한 문항
으로 구성되어 있는데, 본 연구에서는 이 중에서 증상 점수표만을 사용하여 연구대상자들이 호소하 는 소화불량의 정도를 평가하였다(Table 5).

증상 점수표는 15 가지 증상에 대해 빈도, 강도, 괴로운 정도를 나누어 평가한다. 빈도는 지난 2 주 동안 증상이 나타난 일수에 따라 5단계로 평가하 며, 강도는 심한 정도에 따라 6단계로, 괴로운 정도 는 심한 정도에 따라 5 단계로 평가하였다. 각 증상 의 빈도, 강도, 괴로운 정도의 점수를 합산하여 증 상별 총점을 적고, 15 가지 증상의 모든 총점을 합 산하여 총 NDI-K 점수를 구하였다. 총 NDI-K 점 수가 높을수록 소화불량의 정도가 심한 것으로 평 가하였다. 
Table 5. Nepean Dyspepsia Index-Korean Version (NDI-K)

\section{NDI-K (Nepean dyspepsia index)}

다음의 질문에서는 지난 2 주 동안에 아래의 위장증상들이

얼마나 자주 일어났는지 / 그 증상은 어느 정도 심하였는지 / 또한 얼마나 당신을 괴롭게 하였는지에 대하 여 그 답이 5 가지(또는 6 가지)로 나와 있습니다.

그 중에서 해당되는 번호에 $\bigcirc$ 표 하여 주십시오.

$\begin{array}{llll}\frac{\text { 얼마나 자주 }}{\text { 있었습니까? }} & \begin{array}{l}\text { 증상의 정도는 } \\ \text { 어떠했습니까? }\end{array} & \begin{array}{l}\text { 증상으로 인한 } \\ \text { 괴로운 정도는 } \\ \text { 어떠했습니까? }\end{array} \\ 0=\text { 전혀 없었다. } & 0=\text { 전혀 없었다. } \\ 1=\text { 하루에서 } 4 \text { 일 } & 1=\text { 매우 약하였다. } & 0=\text { 전혀 없었다. } \\ 2=5 \text { 일에서 } 8 \text { 일 } & 2=\text { 약하게 나타났다. } & 1=\text { 매우 미약하였다. } \\ 3=9 \text { 일에서 } 12 \text { 일 } & 3=\text { 조금 심하였다. } & 2=\text { 미약하였다. } \\ 4=\text { 매일, 거의 매일 } & 4=\text { 심하였다. } & 3=\text { 심하였다. } \\ & 5=\text { 매우 심하였다. } & 4=\text { 매우 심하였다. }\end{array}$

\begin{tabular}{|c|c|c|c|c|c|c|c|c|c|c|c|c|}
\hline 상복부의 통증 & $\begin{array}{lll}0 & 1 & 2\end{array}$ & 34 & 0 & 12 & 3 & 4 & 5 & 0 & 1 & 2 & 3 & 4 \\
\hline 상복부의 불쾌함 & $\begin{array}{lll}0 & 1 & 2\end{array}$ & 34 & 0 & 12 & 3 & 4 & 5 & 0 & 1 & 2 & 3 & 4 \\
\hline 상복부의 쓰림 & $\begin{array}{lll}0 & 1 & 2\end{array}$ & 34 & 0 & 12 & 3 & 4 & 5 & 0 & 1 & 2 & 3 & 4 \\
\hline 가슴쓰림 & $\begin{array}{lll}0 & 1 & 2 \\
\end{array}$ & 34 & 0 & 12 & 3 & 4 & 5 & 0 & 1 & 2 & 3 & 4 \\
\hline 상복부의 경련 & $\begin{array}{lll}0 & 1 & 2 \\
\end{array}$ & 34 & 0 & 12 & 3 & 4 & 5 & 0 & 1 & 2 & 3 & 4 \\
\hline 가슴의 통증 & $0 \quad 12$ & 34 & 0 & 12 & 3 & 4 & 5 & 0 & 1 & 2 & 3 & 4 \\
\hline $\begin{array}{l}\text { 조기만복감 } \\
\text { (보통 분량의 식사를 먹지 못함) }\end{array}$ & $\begin{array}{lll}0 & 1 & 2\end{array}$ & 34 & 0 & 12 & 3 & 4 & 5 & 0 & 1 & 2 & 3 & 4 \\
\hline $\begin{array}{l}\text { 위산 역류 } \\
\text { (신물 또는 쓴 물이 위로 올라옴) }\end{array}$ & $\begin{array}{lll}0 & 1 & 2\end{array}$ & 34 & 0 & 12 & 3 & 4 & 5 & 0 & 1 & 2 & 3 & 4 \\
\hline $\begin{array}{l}\text { 식후 포만감 } \\
\text { (식사 후 속이 그득하고 더부룩함) }\end{array}$ & $\begin{array}{lll}0 & 1 & 2\end{array}$ & 34 & 0 & 12 & 3 & 4 & 5 & 0 & 1 & 2 & 3 & 4 \\
\hline 상복부의 압박감 & $\begin{array}{lll}0 & 1 & 2 \\
\end{array}$ & 34 & 0 & 12 & 3 & 4 & 5 & 0 & 1 & 2 & 3 & 4 \\
\hline 상복부 팽만감 & $\begin{array}{lll}0 & 1 & 2 \\
\end{array}$ & 34 & 0 & 12 & 3 & 4 & 5 & 0 & 1 & 2 & 3 & 4 \\
\hline 구역, 메스꺼움 & $\begin{array}{lll}0 & 1 & 2 \\
\end{array}$ & 34 & 0 & 12 & 3 & 4 & 5 & 0 & 1 & 2 & 3 & 4 \\
\hline 트림 & $\begin{array}{lll}0 & 1 & 2 \\
\end{array}$ & 34 & 0 & 12 & 3 & 4 & 5 & 0 & 1 & 2 & 3 & 4 \\
\hline 구토 & $\begin{array}{lll}0 & 1 & 2 \\
\end{array}$ & 34 & 0 & 12 & 3 & 4 & 5 & 0 & 1 & 2 & 3 & 4 \\
\hline 숨쉬기가 좋지 않음 & $\begin{array}{lll}0 & 1 & 2 \\
\end{array}$ & 34 & 0 & 12 & 3 & 4 & 5 & 0 & 1 & 2 & 3 & 4 \\
\hline
\end{tabular}


7) 비만(痞滿) 평가의 시각적 상사 척도(VAS) 연구대상자들이 느끼는 心下部의 痁滿(명치 끝 이 답답하고 더부룩한 느낌)의 정도를 측정하기 위해 시각적 상사 척도(Visual Analog Scale, VAS) 를 사용하였다(Table 6). 먼저 비만 증상 유무를 묻고, 증상이 있을 경우 지난 2주 동안 어느 정도 로 불편했는지에 대해 $100 \mathrm{~mm}$ 의 가로선 위에 직접
사선을 그어 표시하게 하였다. $100 \mathrm{~mm}$ 의 가로선에 서 $0 \mathrm{~mm}$ 지점은 '없음'으로, $100 \mathrm{~mm}$ 지점은 '매우 심한 정도'로 지정하였다. $0 \mathrm{~mm}$ 지점에서 대상자 가 표시한 지점까지의 거리를 자로 측정하여 점수 를 구하였으며, 점수가 높을수록 비만의 정도가 심 한 것으로 평가하였다.

Table 6. Visual Analogue Scale of Distention and Fullness

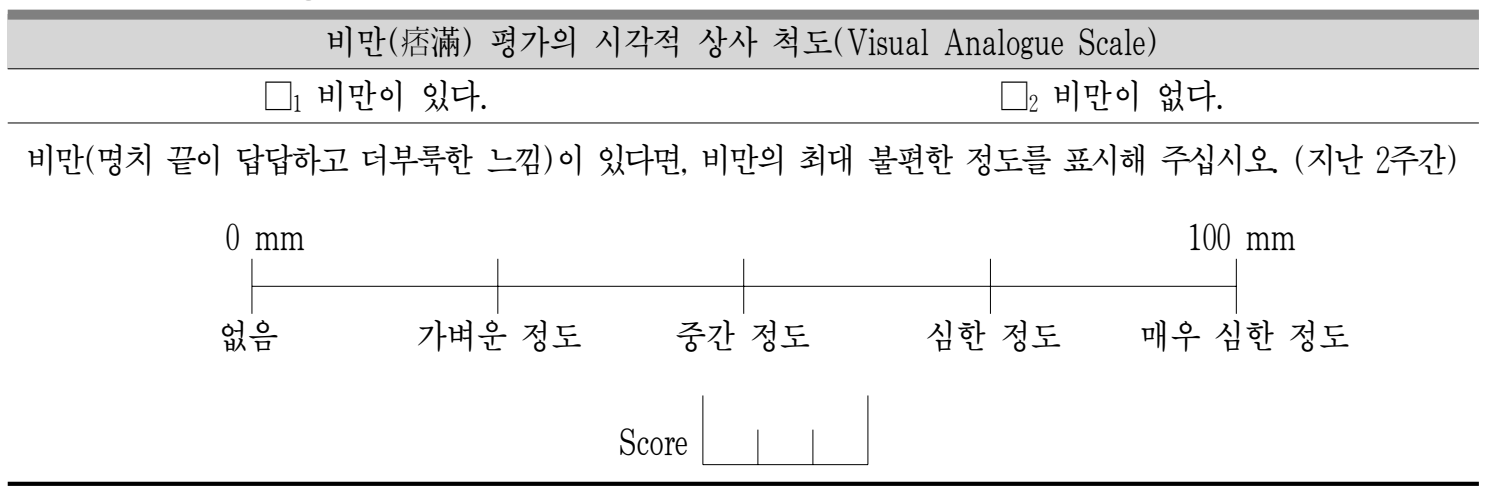

\section{3. 통계분석}

수집된 자료는 Mean \pm Standard deviation(S.D.) 또는 Number(\%)로 나타내었다. 일반적 특성 중 연령, $\mathrm{BMI}$ 의 평균 비교 및 위 배출능 측정 수치를 포함한 각 지표들의 평균 비교는 Mann-Whitney U-test를 이용하였고, 일반적 특성 중 성비에 대한 비교는 Pearson's chi-square test를 이용하였으며, 위 배출능(반감기)과 위기허증의 정도(SSQD 점수), 삶의 질 수준(FD-QoL 점수), 소화불량의 정도(NDI-K 점수) 및 비만의 정도(VAS 점수)와의 상관관계는 Spearman correlation analysis를 이용하여 분석하 였다. 모든 통계분석은 PASW Statistics 18(SPSS Inc., Chicago, IL, USA) 프로그램으로 수행하였으며, $\mathrm{p}$ 값( $\mathrm{p}$-value $<0.05$ 인 경우를 통계적으로 유의하다 고 판정하였다.

\section{III. 결 과}

\section{1. 일반적 특성}

총 20 명의 연구대상자 중 환자군과 대조군은 각 각 10 명씩이며, 환자군에서 남성은 4 명 $(40 \%)$, 여성 은 6 명 $(60 \%)$ 이었고, 대조군에서 남성은 5 명 $(50 \%)$, 여성은 5 명 $(50 \%)$ 으로 두 군 간의 성비에 통계적으 로 유의한 차이는 없었다 $(\mathrm{p}=0.653)$. 평균 연령은 환자군 29.60세, 대조군 26.70세로 환자군이 대조군 보다 높았으나, 통계적으로 유의한 차이는 없었다 ( $\mathrm{p}=0.484$ ). BMI는 환자군의 경우 평균 $19.64 \mathrm{~kg} / \mathrm{m}^{2}$, 대조군의 경우 평균 $21.31 \mathrm{~kg} / \mathrm{m}^{2}$ 으로 대조군이 환 자군보다 높았으나, 통계적으로 유의한 차이는 없 었다 $(\mathrm{p}=0.173)$ (Table 7). 
Table 7. Clinical Characteristics of Subjects

\begin{tabular}{|c|c|c|c|c|}
\hline \multirow{2}{*}{ Characteristics } & \multirow{2}{*}{ Patient group $(\mathrm{n}=10)$} & \multirow{2}{*}{ Control group $(n=10)$} & \multicolumn{2}{|r|}{$p$ value } \\
\hline & & & $x^{2}$-test & Mann-Whitney U-test \\
\hline Male (\%) & $4(40 \%)$ & $5(50 \%)$ & \multirow{2}{*}{.653} & \\
\hline sex Female (\%) & $6(60 \%)$ & $5(50 \%)$ & & \\
\hline Age (year) & $29.60 \pm 6.65$ & $26.70 \pm 1.1$ & & .484 \\
\hline $\operatorname{BMI}\left(\mathrm{kg} / \mathrm{m}^{2}\right)$ & $19.64 \pm 2.95$ & $21.31 \pm 2.13$ & & .173 \\
\hline
\end{tabular}

$\mathrm{n}:$ number of subjects, BMI : body mass index

Values are mean \pm standard deviation.

\section{2. 환자군과 대조군 간의 각종 지표 비교}

$\mathrm{PDS}$ 유형에 속하는 10 명의 환자군과 소화불량 이 없는 10 명의 대조군 사이에 위 배출능, SSQD, FD-QoL, NDI-K 및 비만의 VAS 점수를 비교하 였고, 다음과 같은 결과를 얻었다(Table 8).

1) 위 배출능의 비교

위 배출능은 위의 용적이 식후 최대 확장 시에 서 줄어들 때 식전과의 차이에서의 절반으로 줄어 드는 시점인 반감기 $\left(T_{1 / 2}\right)$ 로 비교하였다. 그 결과 환자군 10 명에서 평균 38.66 분, 대조군 10 명에서 평 균 24.38분으로 환자군의 $T_{1 / 2}$ 가 대조군에 비해 더 길었으며, 이는 통계적으로 유의한 차이를 보였다 $(\mathrm{p}=0.004)$ (Table 8) (Fig. 3A).

2) $\mathrm{SSQD}$ 점수의 비교

위기허증의 정도를 나타내는 SSQD 점수의 경 우, 환자군이 평균 28.90점, 대조군이 평균 11.20점 으로 환자군에서 더 높았으며, 이는 통계적으로 유 의한 차이가 있었다( $\mathrm{p}\langle 0.001)$ (Table 8). 또한 모든
환자군이 최적절삭점인 14 점을 초과하여 위기허증 으로 진단되었고, 모든 대조군이 14점 이하로 나와 위기허증이 아닌 것으로 진단되었다(Fig. 3B).

3) FD-QoL 점수의 비교

기능성소화불량 환자의 삶의 질을 평가하는 척도인 FD-QoL 점수의 경우, 환자군이 평균 66.00 점, 대조 군이 평균 35.40점으로 환자군에서 더 높았으며, 이는 통계적으로 유의한 차이가 있었다 $(\mathrm{p}=0.001$ ) (Table 8).

4) NDI-K 점수의 비교

소화불량 증상의 정도를 나타내는 NDI-K 점수 의 경우, 환자군이 평균 57.70점, 대조군이 평균 15.60점으로 환자군에서 더 높았으며, 이는 통계적 으로 유의한 차이가 있었다 $(\mathrm{p}=0.001$ ) (Table 8 ).

5) 비만의 VAS 점수의 비교

비만의 정도를 나타내는 VAS 점수를 비교해본 결과 환자군이 평균 58.20점, 대조군이 평균 7.50점 으로 환자군에서 더 높게 측정되었고, 이는 통계적 으로 유의한 차이를 보였다( $\mathrm{p}<0.001$ ) (Table 8).

Table 8. Comparisons of the Value of $T_{1 / 2}$, SSQD Score, FD-QoL Score, NDI-K Score, and VAS of Distention and Fullness between Patient Group and Control Group

\begin{tabular}{cccc} 
& Patient group $(\mathrm{n}=10)$ & Control group $(\mathrm{n}=10)$ & $p$ value \\
\hline$T_{\mathrm{i} / 2}$ (min) & $38.66 \pm 10.13$ & $24.38 \pm 7.19$ & $.004^{*}$ \\
SSQD score & $28.90 \pm 4.23$ & $11.20 \pm 2.79$ & $\left\langle 0.001^{*}\right.$ \\
FD-QoL score & $66.00 \pm 16.14$ & $35.40 \pm 10.06$ & $.001^{*}$ \\
NDI-K score & $57.70 \pm 29.95$ & $15.60 \pm 7.41$ & $.001^{*}$ \\
VAS of distention and fullness & $58.20 \pm 12.76$ & $7.50 \pm 8.69$ & $\left\langle 0.001^{*}\right.$ \\
\hline
\end{tabular}

$\mathrm{n}$ : number of subjects, $T_{1 / 2}:$ half-life of gastric volume, SSQD : scale for Stomach Qi Deficiency pattern, FD-QoL : functional dyspepsia related quality of life, NDI-K : Nepean dyspepsia index-Korean version, VAS : visual analog scale Values are the mean \pm standard deviation.

P-value is calculated by Mann-Whitney U-test.

* : statistically significant difference $(\mathrm{p}<0.05)$ 

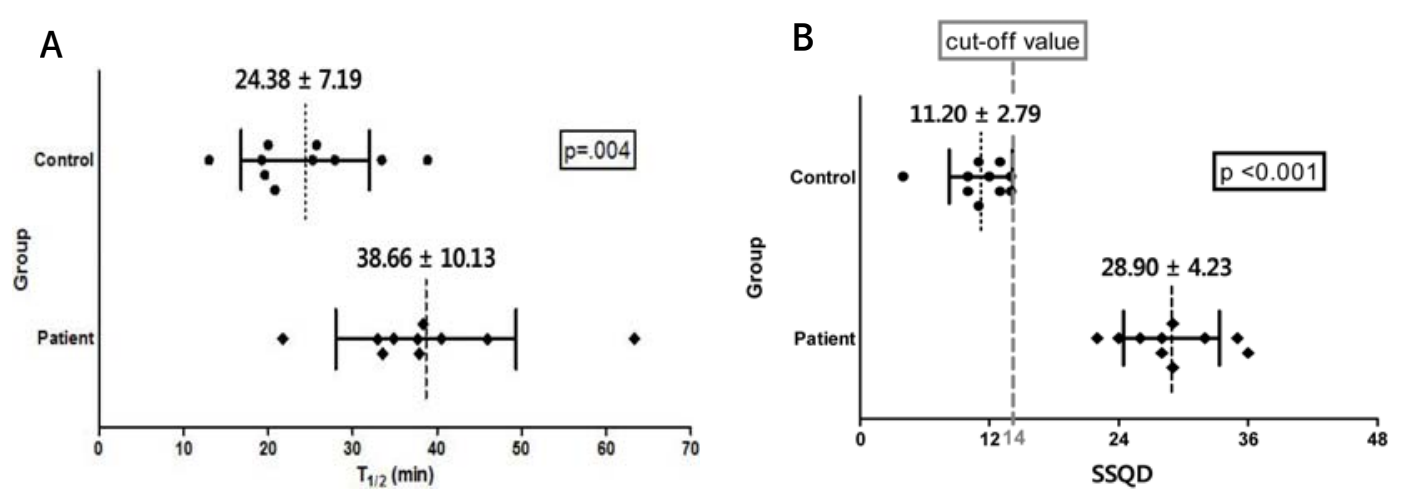

Fig. 3. (A) Comparison of $T_{1 / 2}$ (half-life of gastric volume) values measured by abdominal ultrasonography between patient group and control group, (B) Comparison of SSQD (scale for Stomach Qi Deficiency pattern) scores between patient group and control group. Cut-off value of SSQD is 14 .

3. 위 배출능과 위기허증 변증설문지를 포함한 각 종 지표와의 상관성 분석

1) 대상자 전원에서의 상관성 분석 결과 연구대상자 전원의 위 배출능과 SSQD, FD-QoL, $\mathrm{NDI}-\mathrm{K}$ 및 비만의 VAS 점수 간의 상관분석을 시행 한 결과, 위 배출능은 $\mathrm{SSQD}$ 점수, $\mathrm{FD}-\mathrm{QoL}$ 점수, $\mathrm{NDI}-\mathrm{K}$ 점수 및 비만의 VAS 점수와 모두 통계적으로 유의한 양의 상관관계를 보였다( $\mathrm{p}<0.05)$ (Table 9 ).

2) 환자군 내에서의 상관성 분석 결과

환자군 내에서 위 배출능과 SSQD, FD-QOL, NDI-K 및 비만의 VAS 점수 간의 상관분석을 시행한 결과,
위 배출능은 $\mathrm{SSQD}$ 점수와 통계적으로 유의한 양 의 상관관계를 보였다 $(\mathrm{r}=0.640, \mathrm{p}<0.05)$ (Table 9$)$. 반면, $\mathrm{FD}-\mathrm{Q} 0 \mathrm{~L}$ 점수, $\mathrm{NDI}-\mathrm{K}$ 점수 및 비만의 $\mathrm{VAS}$ 점수와는 유의한 상관관계를 보이지 않았다 $(\mathrm{p}>0.05)$ (Table 9).

3) 대조군 내에서의 상관성 분석 결과

대조군 내에서 위 배출능과 SSQD, FD-QoL, NDI-K 및 비만의 $\mathrm{VAS}$ 점수 간의 상관분석을 시행한 결과, 위 배출능은 $\mathrm{SSQD}$ 점수, $\mathrm{FD}-\mathrm{Q} 0 \mathrm{~L}$ 점수, $\mathrm{NDI}-\mathrm{K}$ 점수 및 비만의 $\mathrm{VAS}$ 점수와 모두 통계적으로 유 의한 상관관계를 보이지 않았다(p>0.05) (Table 9).

Table 9. Correlation Analysis between $T_{1 / 2}$ and the Degree of SSQD, FD-QOL, NDI-K, and VAS of Distention and Fullness in All Subjects, Patient Group and Control Group

\begin{tabular}{|c|c|c|c|c|c|c|}
\hline & \multirow{2}{*}{\multicolumn{2}{|c|}{$\frac{\text { All subjects }(\mathrm{n}=20)}{T_{1 / 2}}$}} & \multirow{2}{*}{\multicolumn{2}{|c|}{$\begin{array}{c}\text { Patient group }(\mathrm{n}=10) \\
T_{1 / 2}\end{array}$}} & \multirow{2}{*}{\multicolumn{2}{|c|}{$\frac{\text { Control group }(\mathrm{n}=10)}{T_{1 / 2}}$}} \\
\hline & & & & & & \\
\hline & $r$ & $p$ & $r$ & $p$ & $r$ & $p$ \\
\hline SSQD score & $.669^{+}$ & $.001^{* *}$ & $.640^{\dagger}$ & $.046^{*}$ & .031 & .933 \\
\hline FD-QoL score & $.625^{+}$ & $.003^{* *}$ & .565 & .089 & .134 & .713 \\
\hline NDI-K score & $.662^{+}$ & $.001^{* *}$ & .467 & .174 & -.091 & .803 \\
\hline VAS of distention and fullness & $.662^{+}$ & $.001^{* *}$ & .319 & .369 & .253 & .481 \\
\hline
\end{tabular}

$T_{1 / 2}$ : half-life of gastric volume, SSQD : scale for Stomach Qi Deficiency pattern, FD-QoL : functional dyspepsia related quality of life, NDI-K : Nepean dyspepsia index-Korean version, VAS : visual analog scale

$\mathrm{P}$-value is calculated by Spearman's correlation test.

$r$ : Spearman's correlation coefficient

* : $p<0.05$

$* *: p<0.01$

$\dagger$ : statistically significant correlation (Spearman, two-tailed) 
4) 위 배출능과 위기허증 변증설문지 문항별 상 관성 분석 결과

연구대상자 전원의 위 배출능과 $\mathrm{SSQD}$ 의 12 가지 문항별 점수 간의 상관분석을 시행한 결과, 그 중 '윗배가 항상 답답하고 식후 더 불편하다'에 해당 하는 1 번 문항 $(\mathrm{r}=0.659, \mathrm{p}=0.002)$, '음식 생각이 안나 식욕이 없다'에 해당하는 2 번 문항 $(r=0.518, p=0.019)$, ‘몸이 나른하고 힘이 없다’에 해당하는 3 번 문항 $(\mathrm{r}=0.719, \mathrm{p}<0.001)$, 윗배가 은은하게 아프나 심하
지 않아 따뜻이 해주면 줄어든다'에 해당하는 4 번 문항 $(\mathrm{r}=0.566, \mathrm{p}=0.009)$, “정신적으로 쉽게 피로하 다'에 해당하는 6 번 문항 $(\mathrm{r}=0.606, \mathrm{p}=0.005)$, '얼굴 이 윤기 없이 누렇게 떠 있거나 핏기가 없다'에 해 당하는 7번 문항 $(\mathrm{r}=0.545, \mathrm{p}=0.013)$, '발병일로부터 경과'에 해당하는 9 번 문항 $(r=0 / 659, p=0.002)$, '한 의사의 복진소견'에 해당하는 10 번 문항 $(\mathrm{r}=0.466$, 0.038)에서 각각 위 배출능과 통계적으로 유의한 양의 상관관계를 보였다(Table 10).

Table 10. Correlation Analysis between $T_{1 / 2}$ and SSQD Score

\begin{tabular}{|c|c|c|c|}
\hline \multicolumn{4}{|c|}{ All subjects $(n=20)$} \\
\hline \multirow{2}{*}{\multicolumn{2}{|c|}{ Question }} & \multicolumn{2}{|c|}{$T_{1 / 2}$} \\
\hline & & $r$ & $p$ \\
\hline Q1 & Discomfort in upper abdomen after meals & $.659^{\dagger}$ & $.002^{* *}$ \\
\hline Q2 & No appetite for food & $.518^{\dagger}$ & $.019^{*}$ \\
\hline Q3 & Lethargy and weakness of body & $.719^{\dagger}$ & $<0.001^{* *}$ \\
\hline Q4 & Mild pain on the upper abdomen that is relieved by warmness & $.566^{\dagger}$ & $.009^{* *}$ \\
\hline Q5 & Frequent belching & .085 & .721 \\
\hline Q6 & Emotionally tired easily & $.606^{\dagger}$ & $.005^{* *}$ \\
\hline Q7 & A sallow or pale face & $.545^{\dagger}$ & $.013^{*}$ \\
\hline Q8 & Unable to distinguish the taste of foods & .366 & .112 \\
\hline Q9 & Time from onset & $.659^{\dagger}$ & $.002^{* *}$ \\
\hline Q10 & Abdominal diagnosis of a Korean medicine doctor & $.466^{\dagger}$ & $.038 *$ \\
\hline Q11 & Pulse diagnosis of a Korean medicine doctor & .310 & .184 \\
\hline Q12 & Tongue diagnosis of a Korean medicine doctor & .312 & .181 \\
\hline $\begin{array}{l}T_{1 / 2}: h \\
\mathrm{P}-\mathrm{v} \text { alue } \\
r: \text { Spea } \\
*: p<0 \\
* *: p<\end{array}$ & $\begin{array}{l}\text {-life of gastric volume } \\
\text { calculated by Spearman's correlation test. } \\
\text { han's correlation coefficient } \\
1\end{array}$ & & \\
\hline
\end{tabular}

5) 위 배출능과 NDI-K 문항별 상관성 분석 결과 연구대상자 전원의 위 배출능과 NDI-K의 15 가 지 문항별 점수 간의 상관분석을 시행한 결과, 그 중 '상복부의 불쾌함'에 해당하는 2 번 문항 $(\mathrm{r}=0.566$, $\mathrm{p}=0.009)$, '조기만복감'에 해당하는 7번 문항 $(\mathrm{r}=0.676$, $\mathrm{p}=0.001)$, '식후 포만감'에 해당하는 9 번 문항 $(\mathrm{r}=0.559$, $\mathrm{p}=0.01$ ), '상복부의 압박감'에 해당하는 10 번 문항 $(\mathrm{r}=0.685, \mathrm{p}=0.001)$, '구역, 메스꺼움'에 해당하는 12번 문항 $(\mathrm{r}=0.470, \mathrm{p}=0.036)$ 에서 각각 위 배출능과 통 계적으로 유의한 양의 상관관계를 보였다(Table 11). 
Table 11. Correlation Analysis between $T_{1 / 2}$ and NDI-K Score

\begin{tabular}{llcc} 
& & & \\
\multicolumn{1}{c}{ Question } & \multicolumn{2}{c}{$T_{1 / 2}$} \\
\cline { 3 - 4 } & & $r$ & $p$ \\
\hline Q1 & Pain in upper abdomen & .344 & .138 \\
Q2 & Discomfort in upper abdomen & $.566^{+}$ & $.009^{* *}$ \\
Q3 & Burning in upper abdomen & .286 & .221 \\
Q4 & Heartburn & .227 & .336 \\
Q5 & Cramps in upper abdomen & .409 & .073 \\
Q6 & Chest pain & .280 & .232 \\
Q7 & Inability to finish regular meal & $.676^{\dagger}$ & $.001^{* *}$ \\
Q8 & Bitter tasting fluid that comes to your mouth & .332 & .153 \\
Q9 & Fullness after eating & $.559^{\dagger}$ & $.010^{*}$ \\
Q10 & Pressure in upper abdomen & $.685^{+}$ & $.001^{* *}$ \\
Q11 & Bloating in upper abdomen & .371 & .108 \\
Q12 & Nausea & $.470^{+}$ & $.036^{*}$ \\
Q13 & Belching & .128 & .590 \\
Q14 & Vomiting & .381 & .097 \\
Q15 & Bad breath & .354 & .126 \\
\hline
\end{tabular}

$T_{1 / 2}:$ half-life of gastric volume

P-value is calculated by Spearman's correlation test.

$r$ : Spearman's correlation coefficient

* : $p<0.05$

**: $: p<0.01$

$\dagger$ : statistically significant correlation (Spearman, two-tailed)

\section{IV. 고 찰}

기능성소화불량은 위장관 증상이 만성적이고 반 복적으로 발생하는 증상군으로서, 그 병태생리는 아직까지 명확히 밝혀진 바 없으나, 매우 복잡하며 한 가지 기전만으로는 설명되지 않고 몇 가지 기전 들이 관여하는 것으로 알려져 있다. 일차적으로는 위 운동 이상이 병태생리에 관여하는 것으로 알려 져 있는데, 이전 연구 ${ }^{5}$ 에서 기능성소화불량 환자의 경우 정상인에 비해 위 배출이 1.5 배 지연되어 있 고, 기능성소화불량 환자의 $40 \%$ 가 위 배출 장애를 보인다고 보고하였다. 또한 기능성소화불량 환자 중에서 위 배출이 지연되어있는 경우 조기 만복감 이나 포만감을 호소하는 비율이 유의하게 높은 것
으로 나타났다 ${ }^{27}$. 그 외에도 위저부 조절 장애, 내 장과민성, 정신질환 및 스트레스가 병태생리에 관 여하며 기능성소화불량의 증상 정도에도 영향을 미치는 것으로 알려져 있다.

기능성소화불량의 유형은 그 증상에 따라 식후 불편감증후군(postprandial distress syndrome, PDS)과 상복부통증증후군(epigastric pain syndrome, EPS) 으로 나뉘는데, $\mathrm{PDS}$ 는 식후 포만감과 조기 만복감 증상을, $\mathrm{EPS}$ 는 중등도의 명치 통증이나 속쓰림을 호소하는 경우를 말한다. 유형별 국내 유병률은 PDS 가 $5.6 \%, \mathrm{EPS}$ 가 $4.2 \%$ 이며 ${ }^{3}$, 서양인에 비해 동양인의 경우 특히 PDS가 더 흔하다고 알려져 있다 ${ }^{28}$. 또한 $\mathrm{EPS}$ 는 위의 운동성 및 기능과의 연관성이 적은 반 면, $\mathrm{PDS}$ 는 위 배출 장애, 위의 감각과민, 불안 등 
과 관련이 있는 것으로 보고된 바 있다 ${ }^{6.29}$. Kugler ${ }^{30}$ 는 기능성소화불량 환자를 대상으로 유형을 분류한 뒤 초음파를 통해 위 배출능을 평가한 결과, $\mathrm{EPS}$ 보다 PDS가 위장 운동 장애와 더 유의한 상관성 이 있는 것으로 보고하였다. 이처럼 기능성소화불 량 환자에서 위 배출능은 중요한 지표가 될 수 있 으며 특히 PDS 유형에서 더 의미 있는 지표가 될 수 있다.

이러한 위 배출능을 평가하는 방법으로 초기에 는 바륨과 음식물을 혼합하여 섭취한 뒤 X-ray를 통해 확인하는 방법이 사용되었으나, 바륨이 음식 물에서 쉽게 분리되어 위 점막에 붙어 정확한 측 정이 불가능 하였다. 삽관법을 이용하여 튜브를 위에 삽관한 후 위 내용물을 흡인하여 위 배출능 을 분석하는 방법도 있으나, 검사법이 침습적이고 경비위내 삽관을 자주 해야 한다는 단점이 있어 널리 사용되지 않고 있다. 최근 가장 많이 시행되고 있는 검사법은 신티그래피(scintigraphy)이며 주로 고형상 위배출 신티그래피를 많이 사용하는데, 이는 위 배출능을 평가하는 표준 금본위 검사(gold standard test)이다 ${ }^{11}$. 신티그래피는 방사성 동위원소를 이용 하는 검사로, 방사선물질을 사용하는 다른 검사법 에 비해 노출량이 적고 정량분석이 가능하며 비침 습적인 검사라라는 장점이 있긴 하지만, 결국 동위 원소에 노출이 되어야 하므로 환자들이 거부감을 일으킬 수 있다는 단점이 있다 ${ }^{12}$. 이외에도 무선운 동캡슐검사(wireless motility capsule test), 위배출 호기검사(gastric emptying breath test, GEBT), 자 기공명영상(magnetic resonance imagine, MRI) 등 이 있으나, 기술적 한계와 고비용, 복잡성 등으로 인해 잘 시행되지 않는다 ${ }^{10}$. 이와 달리 초음파 검사 는 비침습적이고 비용이 저렴하며 검사하기에 편 리하고 환자에게 방사선 노출의 위험이 없다 ${ }^{13}$. 또 한 실제 위장의 움직임과 음식물의 소화 과정을 모 니터를 통해 실시간으로 볼 수 있기 때문에 환자 에게 설명하기에도 용이한 검사이다 ${ }^{32}$.

초음파를 통해 위 배출능을 평가하기 위해서는
다양한 지표를 이용할 수 있다. 이전 연구들에서 사 용된 지표들을 살펴보면, 위배출반감시간 (Gastric emptying half time, GET50), 위완전배출시간(Total gastric emptying time, GET), 위배출율(Gastric emptying rate, GER), 전정부수축빈도(Frequency of antral contractions), 전정부수축진폭(Amplitude of antral contractions), 운동지수(Motility index, $\mathrm{MI}$; (전정부수축빈도)×(전정부수축진폭)) 등이 있 다. ${ }^{10}$ 본 연구에서는 시간적 효율성과 측정의 편리 성을 고려하여 GET50 지표에서 착안한 반감기 (half-life of gastric volume, 이하 $T_{1 / 2}$ ) 를 이용하였다. $T_{1 / 2}$ 를 구하기 위해서는 먼저, 위 전체 용적을 알아야한다. Van de Puttel 등에 따르면 초음파를 통해 위 전정부(antrum)의 단면적을 측정하여 위 전체 용적을 계산할 수 있다. 초음파 측정부위로 위 전정부(antrum)를 선택한 이유는 위 체부(body)의 경우 공기(air)가 시야를 방해하여 측정의 어려움 이 있고, 위 저부(fundus)는 해부학적으로 늑골(rib) 에 가려져있으므로 마찬가지로 측정의 어려움이 있 기 때문이다 ${ }^{20}$. 초음파를 통해 위 전정부를 촬영한 후 단면적 값을 계산하여 전체 위 용적을 구하는 방법은 Perlas 등리 제시한 공식을 사용하였으며, 이를 적용하기 위해서는 몇 가지 조건이 필요하다. 환자의 나이는 18-85세, BMI는 $19-40 \mathrm{~kg} / \mathrm{m}^{2}$ 여야 하고 임산부는 제외시키며 측정 시 우측 측와위를 유지하고 초음파 탐색자는 시상면(sagittal plane) 으로 대고 측정해야한다.

고형식의 경우 유동식, 액상 식이에 비해 위 배 출 시간이 길며 증상이 심한 환자들은 섭취하기 어렵고 초음파를 통한 위 배출능 측정 연구에서 주로 액체 (물, 주스, 우유 등)나 유동식을 많이 사 용하였다 ${ }^{33}$. 이에 따라 본 연구에서는 오렌지 주스 $(500 \mathrm{ml}, 225 \mathrm{kcal})$ 를 사용하였는데, 용량과 칼로리 에 있어 백 등 ${ }^{16}$ 의 연구와 동일한 조건을 사용하여 연구 결과 값을 비교하고자 하였다. 마찬가지로 위 에서 채택한 위 용적 산출 공식과 $T_{1 / 2}$ 값을 구하 는 방법도 백 등희 읜구와 동일하게 하였다. 
한의학에서 소화기를 대표하는 장기는 비위(脾 胃)로, 비(脾)와 위(胃)는 중초(中焦)에 위치하면 서 경맥(經脈)을 통해 상호 연계되어 있으며, 서로 다른 기능을 가지고 있지만 이들이 상호 배합함으 로써 비위계통(脾胃系統)을 형성하여 소화기능을 수행하게 된다 ${ }^{18}$. 그 중 위(胃)는 수납(受納)과 부 숙(腐熟)의 기능을 담당하는 장기로, 이러한 위의 기능을 의미하는 위기(胃氣)는 수곡(水穀)으로부 터 발생하는 정기(正氣)를 만드는 근본이 되며, 광 의의 위기(胃氣)는 소화기능 전체를 아우르는 기 능을 의미하게 된다 ${ }^{17}$. 이러한 위기(胃氣)가 부족한 상황을 위기허증(胃氣虛證)이라 하는데, 식후 위완 비만(胃脘㿋滿)하는 특징이 있으며 이외에도 식후 불화(食後不化), 불사음식(不思飲食), 시작애기(時 作噯氣), 대변불실(大便不實), 설담태소(舌淡苔少), 맥세약(脈細弱) 등의 증상이 나타난다 ${ }^{18}$. 이처럼 위 기허증(胃氣虛證) 은 소화기 증상뿐만 아니라 허증 (虛證) 과 관련된 전신적인 증상까지 나타나는 증 후로, 이는 기능성소화불량의 증상적 특징과 유사 하며 특히 PDS 유형과 밀접한 관련이 있다.

이미 이전에 백 등 ${ }^{16}$ 이 비기허증(脾氣虛證)과 위 배출능의 상관성에 대한 연구를 진행한 바 있으나. 앞서 언급하였듯이 위기허증(胃氣虛證)이 기능성 소화불량 중 $\mathrm{PDS}$ 유형과의 증상적 연관성이 더 높으며, 백 등 ${ }^{16}$ 이 “위기허증(胃氣虛證)과의 상관성 을 분석하는 것도 필요하다.”라고 추후 위기허증 (胃氣虛證)과 위 배출능과의 상관성 분석의 필요 성을 강조한 바 있다. 또한 한의학에 기초하여 초 음파 검사를 활용하기 위해서는, 해당 질환과 관련 성 높은 변증유형과의 상관성을 밝혀 한의학 진단 의 한 방법으로 초음파를 활용할 과학적 근거를 마련하는 것이 필요하다. 따라서 본 연구는 백 등 ${ }^{16}$ 이 시행한 연구의 연장선으로, 백 등 $^{16}$ 이 채택한 진 단평가도구 중 연구 결과에서 유의한 상관관계가 나오지 않은 식적, 담음, 한열, 허실 설문지를 제외 하였고, 위기허증 변증설문지(SSQD) 및 이와 비교 기준이 될 기능성소화불량 삶의 질 설문지 $(\mathrm{FD}-\mathrm{Q} \mathrm{LL})$,
한국판 Nepean 소화불량증 설문지(NDI-K), 비만 (㾂滿)의 시각적 상사 척도(VAS)를 시행하였다.

본 연구는 환자-대조군 연구이자 예비연구로, 총 20 명의 연구대상자 중 기능성소화불량의 PDS 유 형 환자군(이하 환자군) 10 명, 건강인 대조군(이하 대조군) 10 명을 모집하여 연구를 진행하였다. 두 군의 인구학적 특성은 성비(남성:여성)의 경우 환 자군에서 $4: 6$, 대조군에서 $5: 5$ 로 통계적으로 유의

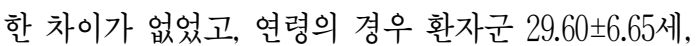
대조군 $26.70 \pm 1.1$ 세로 통계적으로 유의한 차이가 없었으며, BMI의 경우도 환자군 $19.64 \pm 2.95 \mathrm{~kg} / \mathrm{m}^{2}$, 대조군 $21.31 \pm 2.13 \mathrm{~kg} / \mathrm{m}^{2}$ 로 통계적으로 유의한 차 이가 없었다.

환자군과 건강군의 SSQD, FD-QoL, NDI-K, 비 만의 VAS 점수 및 위 배출능을 비교하였을 때, 모 든 항목에서 두 군 간에 유의한 차이를 보였다. 첫 째로 $\mathrm{SSQD}$ 점수의 경우, 환자군 $28.90 \pm 4.23$, 대조 군 $11.20 \pm 2.79$ 로 환자군에서 유의하게 높았다. 특히, 모든 환자군이 위기허증을 판단하는 최적절삭점인 14 점을 초과 하였으며, 마찬가지로 모든 건강군이 14점 이하로 나타났다. 둘째로 FD-QoL 점수의 경 우, 환자군 $66.00 \pm 16.14$, 대조군 $35.40 \pm 10.06$ 로 환자 군에서 유의하게 높았으며, 이는 환자군에서 삶의 질이 저하되어 있음을 의미한다. 셋째로, NDI-K 점수의 경우, 환자군에서 $57.70 \pm 29.95$, 대조군에서 $15.60 \pm 7.41$ 로 환자군에서 유의하게 높았다. 특히 환 자군의 경우 표준편차가 상당히 높게 나왔는데, 이 는 같은 $\mathrm{PDS}$ 유형이라 할지라도 증상의 빈도, 강 도, 괴로운 정도는 개개인마다 차이가 큼을 알 수 있다. 넷째로 비만의 VAS 점수는 환자군이 $58.20 \pm 12.76$,

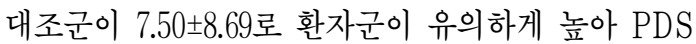
유형의 환자가 식후 비만의 증상을 많이 호소하는 것을 알 수 있고, 이는 PDS 유형의 증상인 식후 팽만감과 관련이 있는 것으로 볼 수 있다. 마지막 으로, 위 배출능의 경우는 위 용적이 반으로 줄어 드는 시점인 반감기 $\left(T_{1 / 2}\right)$ 를 통해 비교하였는데, 그 값이 환자군은 $38.66 \pm 10.13$, 대조군은 $24.38 \pm 7.19$ 
로 환자군에서 유의하게 높았다. 즉, 환자군이 대 조군에 비해 위 배출능이 유의하게 지연되었고, 두 군의 값이 Quartero 등 ${ }^{5}$ 의 분석결과와 유사한 약 1.5 배의 차이를 보였다. 또한, 동일한 방법으로 시 행된 백 등 ${ }^{16}$ 의 연구 결과 값인 환자군 $42.31 \pm 25.09$, 대조군 $24.11 \pm 10.92$ 와 평균값이 상당히 유사하다. 이는 추후 같은 검사법을 이용한 위 배출능 측정 결과 값이 누적됨에 따라 해당 검사법에서 환자군 의 위배출반감기 기준치를 제시하는 데 기여할 것 으로 사료된다.

본 연구의 목표는 위 배출능과 위기허증의 상관 성 유무를 밝히는 것이었다. 또한, 얼마나 유의한 상관관계가 있는지 확인하기 위해 두 지표의 상관 성 분석뿐만 아니라 기준이 될 만한 지표 중 기존 에 기능성소화불량 환자에게 많이 시행하고 있는 FD-QoL, NDI-K 및 비만의 VAS와 위 배출능의 상관성 분석도 추가로 시행하였다. $\mathrm{SSQD}$ 의 경우 이 등 ${ }^{23}$ 이 2017년 개발한 설문지로, 총점을 통해 위 기허증의 정도를 평가하고 최적절삭점을 통해 진 단까지 할 수 있다. 하지만, 최근에 개발되어 아직 은 임상 데이터가 부족한 실정이다. 환자군과 대조 군을 포함한 모든 대상자들에서 지표 값의 상관성 을 분석한 결과 위 배출능을 반영하는 반감기 $\left(T_{1 / 2}\right)$ 와 $\mathrm{SSQD}$ 점수 사이에는 통계적으로 유의한 양의 상관관계를 보였으며 $(\mathrm{r}=0.669, \mathrm{p}=0.001)$, 그 외에 도 $\mathrm{FD}-\mathrm{Q} 0 \mathrm{~L}, \mathrm{NDI}-\mathrm{K}$, 비만의 $\mathrm{VAS}$ 점수 모두 유의 한 양의 상관관계를 보였으며 유의성이 높게 나타 났다( $\mathrm{p}<0.01)$. 이는 백 등 $^{16}$ 의 연구 결과 중 NDI-K, 비만의 VAS 점수가 유의한 상관관계를 보이지 않 은 것과는 상반되는 결과이다. 따라서 본 연구의 결과만 보면, 모든 지표들이 위 배출능과 상관성이 있는 것으로 나타나 PDS 유형의 환자에게 SSQD 를 시행하는 데 큰 이점이 없을 것으로 사료될 수 있다.

그러나 실제 임상에서는 건강인 보다는 주로 환 자를 대상으로 설문지 및 검사가 시행될 것이기 때문에 대상자 전체에서의 상관성보다는 환자군
내에서의 상관성을 분석하는 것이 더 중요하다. 따 라서, 저자는 각 군 내에서의 상관성 분석을 추가 로 시행하였다. 그 결과 환자군 내에서 위배출반감 기 $\left(T_{1 / 2}\right)$ 와 SSQD 점수 사이에는 통계적으로 유의 한 양의 상관관계를 보였으나 $(\mathrm{r}=0.640, \mathrm{p}=0.046)$, 그 외 FD-QoL, NDI-K, 비만의 VAS 점수는 모두 위배출반감기 $\left(T_{1 / 2}\right)$ 와 유의한 상관관계를 보이지 못했다( $p>0.05)$. 건강군 내에서는 모든 지표가 위 배출반감기 $\left(T_{1 / 2}\right)$ 와 유의한 상관관계를 보이지 못 했다 $(\mathrm{p}>0.05)$. 즉, 기능성소화불량 중 $\mathrm{PDS}$ 유형의 환자에게 있어 위기허증의 정도와 위 배출능 사이 에는 상관관계가 있음을 확인할 수 있다. 본 연구 결과를 통해 임상적으로 기능성소화불량 환자 중 $\mathrm{PDS}$ 유형 환자에게 위기허증 진단의 객관적 지표 로서 초음파 검사를 통한 위 배출능의 평가를 활 용할 수 있는 가능성이 높아졌으며, 또한 초음파 검사 시행 주기 사이에 위기허증 변증설문지를 사 용하여 위 배출능을 간접적으로 파악하는데 도움 이 될 것이다.

추가로 $\mathrm{SSQD}, \mathrm{NDI}-\mathrm{K}$ 각각의 문항과 위 배출 능 과의 상관성 분석을 시행하였다. 먼저, NDI-K 의 각 문항과 위 배출능과의 상관성을 분석한 결 과, 총 15 개 문항 중 '상복부의 불쾌함', '조기만복 감', '식후 포만감', '상복부의 압박감', '구역, 메스꺼 움'에서 각각 위 배출능과 통계적으로 유의한 양의 상관관계를 보였다. 이를 통해 상복부의 통증, 쓰 림, 경련, 팽만감보다는 불쾌함, 압박감이 위 배출 능과 관련이 있고, 조기만복감, 식후 포만감은 물 론 구역, 메스꺼움까지도 관련이 있음을 알 수 있 었다. 이와 달리 가슴 쪽 증상을 비롯하여 위산 역 류, 트림, 구토, 숨쉬기가 좋지 않은 증상은 통계적 으로 유의한 상관관계가 없었다.

이어서 $\mathrm{SSQD}$ 의 각 문항과 위 배출능과의 상관 성을 분석하였는데, 총 12 개 문항 중 '윗배가 항상 답답하고 식후 더 불편하다', '음식 생각이 안나 식 욕이 없다', '몸이 나른하고 힘이 없다', '윗배가 은 은하게 아프나 심하지 않아 따뜻이 해주면 줄어든 
다’, ‘정신적으로 쉽게 피로하다’, '얼굴이 윤기 없이 누렇게 떠 있거나 핏기가 없다', '발병일로부터 경 과', '한의사의 복진소견'에서 각각 위 배출능과 통 계적으로 유의한 양의 상관관계를 보였다. SSQD 의 문항은 대부분 환자의 주관적인 증상에 대한 평가 위주이며, 객관화를 위해 한의사의 복진, 맥진, 설진 소견이 있긴 하지만 이 또한 한의사의 주관 이 개입될 수밖에 없는 실정이다. 따라서 설문지의 객관화를 위해 앞서 연관성을 확인한 위 배출능 검사를 시행해 보는 것이 도움이 될 수 있다. 하지 만 단순히 검사를 추가 시행하는 것 보다는 기존 설문지 항목 중 관련성 높은 항목을 대체하는 것 도 한 가지 방법일 수 있겠다. 따라서 앞서 시행한 문항별 상관성 분석 결과에서 통계적으로 유의한 상관관계가 있을 뿐만 아니라 NDI-K 상 유의한 상관관계를 보인 상복부 불쾌감, 압박감, 식후포만 감과 유사한 문항인 '윗배가 항상 답답하고 식후 더 불편하다'가 대체 가능할 것으로 기대된다. 추 후에 이에 대한 추가 연구가 이루어져 정량적 측 면에서 개선된 SSQD가 개발되길 기대해본다.

본 연구의 결과 해석 및 적용에 있어 몇 가지 고려해야할 점들이 존재한다. 첫째로, 본 연구는 예비 연구로 대상자 수가 총 20명 (환자군 10명, 대 조군 10 명)으로 적었기 때문에 연구 결과의 신뢰 성이 떨어질 수 있다. 그러나, 본 연구와 유사한 이 전 연구의 위 배출능 측정값과 본 연구의 결과값 과의 비교를 통해 초음파를 통한 위 배출능 측정 법에 근거를 마련하였으며, 상관성 분석에서는 이 전 연구와는 달리 추가적으로 환자군 내에서의 유 의한 상관관계를 밝혀내어 위기허증 변증설문지와 초음파 기기의 임상적 활용가치를 더욱 극대화하 였다. 둘째로, 초음파 검사의 경우 검사자의 많은 경험을 통한 숙련된 기술이 필요하다 ${ }^{34}$. 이를 위해 본 연구에서는 검사자가 임상연구를 시작하기 전 미리 초음파 촬영 기술을 충분히 익힌 뒤 연구를 시행하였다. 셋째로, 측정 부위가 위(stomach)라는 동적인 장기 특성상 전정부 단면적의 단회 측정이
용적을 얼마나 정확하게 반영할 수 있을지에 대한 의문이 제기될 수 있다 ${ }^{35}$. 따라서 후속 연구에서는 한 검사자가 여러 번 검사하거나 서로 다른 검사 자가 동일한 검사를 시행하여 비교한다면 더욱 정 확한 결과를 얻을 수 있을 것이다. 마지막으로 특 정 환자의 경우, 예를 들면 심한 비만환자, 위장 속 에 공기(air)가 많은 환자, 해부학적으로 위의 모양 이 다른 환자에 있어 초음파를 통한 위 배출능 측 정이 어려울 수 있다 ${ }^{34}$. 실제로 본 연구를 진행하면 서도 대상자마다 전정부의 위치가 다 달랐으며, 특 히 위하수(gastroptosis) 환자의 경우 전정부가 배 꼽(umbilicus) 바로 위에 위치하여 초음파 영상에 서 위 전정부를 촬영하는 데에 어려움이 있었다.

본 연구를 토대로 앞서 언급한 한계점들을 참고 하여 추후 비슷한 주제의 질 높은 대규모 임상 연 구가 진행되기를 바라며, 나아가 본 연구에서처럼 초음파 기기를 활용한 객관적 지표와 한방 진단평 가도구와의 유의성을 검정하는 후속 연구가 계속 진행되기를 기대해본다.

\section{V. 결 론}

기능성소화불량 환자 중 $\mathrm{PDS}$ 유형 환자 10 명과 건강인 대조군 10 명을 대상으로 SSQD, FD-QoL, NDI-K, 비만의 VAS 점수 및 위 배출능을 비교하 고, 더불어 위 배출능과 SSQD, FD-QoL, NDI-K, 비만의 VAS 점수 간의 상관관계를 분석한 결과, 다음과 같은 결론을 얻었다.

1. 전체 연구대상자 20 명 중 환자군과 대조군은 각 각 10 명이었으며, 환자군과 대조군 간에 성비, 연령, $\mathrm{BMI}$ 는 유의한 차이가 없었다.

2. 환자군과 대조군을 비교해봤을 때, 환자군이 대 조군에 비해 위 배출능을 반영하는 반감기 $\left(T_{1 / 2}\right)$ 가 유의하게 높았으며, 그 외 $\mathrm{SSQD}$ 점수, $\mathrm{FD}-\mathrm{QoL}$ 점수, $\mathrm{NDI}-\mathrm{K}$ 점수, 비만의 $\mathrm{VAS}$ 점수도 모두 유의하게 높았다. 
3. 전체 대상자에서 위 배출능을 반영하는 반감기 $\left(T_{1 / 2}\right)$ 는 SSQD 점수, FD-QoL 점수, NDI-K 점 수, 비만의 $\mathrm{VAS}$ 점수와 모두 유의한 양의 상관 관계가 있었다.

4. 환자군 내에서 위 배출능을 반영하는 반감기 $\left(T_{1 / 2}\right)$ 는 $\mathrm{SSQD}$ 점수와 유의한 양의 상관관계에 있었 으나. 그 외 FD-QoL 점수, NDI-K 점수, 비만의 VAS 점수와는 모두 유의한 상관관계가 없었다.

5. 전체 대상자에서 위 배출능을 반영하는 반감기 $\left(T_{1 / 2}\right)$ 는 $\mathrm{SSQD}$ 문항 중 '윗배가 항상 답답하고 식후 더 불편하다', '음식 생각이 안나 식욕이 없다', '몸이 나른하고 힘이 없다', '윗배가 은은 하게 아프나 심하지 않아 따뜻이 해주면 줄어든 다', '정신적으로 쉽게 피로하다', '얼굴이 윤기 없이 누렇게 떠 있거나 핏기가 없다', '발병일로 부터 경과', '한의사의 복진소견'의 점수와 유의 한 양의 상관관계가 있었다.

6. 전체 대상자에서 위 배출능을 반영하는 반감기 $\left(T_{1 / 2}\right)$ 는 NDI-K 문항 중 '상복부의 불쾌함', '조 기만복감', '식후 포만감', '상복부의 압박감', '구 역, 메스꺼움'의 점수와 유의한 양의 상관관계가 있었다.

위의 결론을 토대로, 기능성소화불량 중 PDS 유 형 환자에서 초음파로 측정한 위 배출능을 위기허 증 진단 중 한 가지 항목으로 활용할 수 있을 것으 로 보인다.

\section{참고문헌}

1. Shin CM, Huh KC. Diagnosis and treatment of functional dyspepsia. Journal of the Korean Medical Association 2016:59(4):311-8.

2. Ford AC, Marwaha A, Sood R, Moayyedi P. Global prevalence of, and risk factors for, uninvestigated dyspepsia: a meta-analysis. Gut 2015:64(7) :1049-57.

3. Min BH, Huh KC, Jung HK, Yoon YH, Choi KD,
Song $\mathrm{KH}$, et al. Prevalence of uninvestigated dyspepsia and gastroesophageal reflux disease in Korea: a population-based study using the Rome III criteria. Digestive Diseases and Sciences 2014; 59(11) :2721-9.

4. Stanghellini V, Chan FK, Hasler WL, Malagelada JR, Suzuki H, Tack J, et al. Gastroduodenal Disorders. Gastroenterology 2016;150(6):1380-92.

5. Quartero AO, de Wit NJ, Lodder AC, Numans ME, Smout AJ, Hoes AW. Disturbed solid-phase gastric emptying in functional dyspepsia: a meta-analysis. Digestive Diseases and Sciences 1998;43(9):2028-33.

6. Shindo T, Futagami S, Hiratsuka T, Horie A, Hamamoto T, Ueki $\mathrm{N}$, et al. Comparison of gastric emptying and plasma ghrelin levels in patients with functional dyspepsia and non-erosive reflux disease. Digestion 2009;79(2):65-72.

7. Committee of Digestive Diseases, National Korean Medicine College. Gastroenterology. Seoul: Koonja publisher; 2009, p. 87.

8. Stempien SJ, Tester RJ, Dagrdi AE. Six hour food and barium retention tests. American Journal of Digestive Diseases 1971;16(5):305-402.

9. Hunt JN. The viscosity of the test meal; Its influence on gastric secretion and emptying. Lancer( $i$ ). 1954;266(6801):17-8.

10. Muresan C, Surdea Blaga T, Muresan L, Dumitrascu DL. Abdominal Ultrasound for the Evaluation of Gastric Emptying Revisited. Journal of gastrointestinal and liver diseases 2015:24(3):329-38.

11. Camilleri M, Parkman HP, Shafi MA, Abell TL, Gerson L. Clinical guideline: management of gastroparesis. American Journal of Gastroenterology 2013;108(1) :18-38.

12. Hong SP. Assessment of gastric emptying using 
three-dimensional ultrasonography. The Korean Journal of Gastroenterology 2004;44(2):103-6.

13. Irvine EJ, Tougas G, Lappalainen R, Bathurst NC. Reliability and interobserver variability of ultrasonographic measurement of gastric emptying rate. Digestive Diseases and Sciences 1993:38(5) :803-10.

14. Lee HW, Park HJ, Lee SI, Park IS, Kang BC, Kim KW. Ultrasonographic Gastric Emptying in Patients with Functional Dyspepsia. Korean Journal of Gastroenterology 1998:31(1):1-8.

15. Kim DY, Jung HK, Lee YH, Jung SA, Moon IW, Paek JY. The Measurement of Gastric Emptying Time with 3-D Ultrasonography. Korean Journal of Gastroenterology 2004;44(2) :71-6.

16. Baek SH, Kim JS. Correlation Analysis between Gastric Emptying Measured by Ultrasonography and Spleen Qi Deficiency Pattern in Patients with Functional Dyspepsia. The Journal of Korean Oriental Internal Medicine 2015:36(4):527-46.

17. Department of Physiology, National Korean Medicine College. Oriental Medical Physiology. Seoul: Jipmoondang publisher; 2008, p. 258-62.

18. Committee of Digestive Diseases, National Korean Medicine College. Gastroenterology. Seoul: Koonja publisher; 2009, p. 67-9.

19. Brun R, Kuo B. Functional dyspepsia. Therapeutic Advances in Gastroenterology 2010:3(3):145-64.

20. Van de Putte P, Perlas A. Ultrasound assessment of gastric content and volume. British Journal of Anaesthesia 2014;113(1):12-22.

21. Bolondi L, Bortolotti M, Santi V, Calletti T, Gaiani S, Labò G. Measurement of gastric emptying time by real-time ultrasonography. Gastroenterology 1985;89(4) :752-9.

22. Perlas A, Mitsakakis N, Liu L, Cino M, Haldipur
N, Davis L, et al. Validation of a Mathematical Model for Ultrasound Assessment of Gastric Volume by Gastroscopic Examination. Anesthesia and Analgesia 2013;116(2):357-63.

23. Lee JH, Park JW, Ko SJ, Kim JS. Development and validation of a new pattern identification scale for Stomach Qi Deficiency. European Journal of Integrative Medicine 2018;17:56-63.

24. Lee EH, Hahm KB, Lee JH, Park JJ, Lee DH, Kim SK, et al. Development and validation of a functional dyspepsia-related quality of life (FD-QOL) scale in South Korea. Journal of Gastroenterology and Hepatology 2006:21(1) :268-74.

25. Talley NJ, Haque M, Wyeth JW, Stace NH, Tytgat GN, Stanghellini V, et al. Development of a new dyspepsia impact scale: the Nepean Dyspepsia Index. Alimentary Pharmacology and Therapeutics 1999;13(2):225-35.

26. Cho YK, Choi MG, Kim SH, Lee IS, Kim SW, Chung IS, et al. The effect of mosapride on quality of life in functional dyspepsia. The Korean journal of gastroenterology 2004;43(3) $: 160-7$.

27. Tack J, Bisschops R, Sarnelli G. Pathophysiology and treatment of functional dyspepsia. Gastroenterology 2004;127(4):1239-55.

28. Mahadeva S, Ford AC. Clinical and epidemiological differences in functional dyspepsia between the East and the West. Journal of Neurogastroenterology and Motility 2016:28(2):167-74.

29. Aro P, Talley NJ, Ronkainen J, Storskrubb T, Vieth M, Johansson SE, et al. Anxiety is associated with uninvestigated and functional dyspepsia (Rome III criteria) in a Swedish population-based study. Gastroenterology. 2009;137(1):94-100.

30. Kugler T. The Usefulness of Water-drinking 
Ultrasonography Combined Test for Evaluating Patients with Functional Dyspepsia. The Korean Journal of Gastroenterology 2015;66(2):92-7.

31. Meyer JH: Invasive (intubation) and non invasive (radionuclide imaging) techniques for studying gastric emptying; in Dubois A, Castell DO(eds):

Esophageal and Gastric Emptying. Baca Raton, CRC Press 1985:73-81.

32. Gilja $\mathrm{OH}$. Ultrasound of the stomach - the EUROSON lecture 2006. Ultraschall Med 2007; 28(1) :32-9.
33. Hillyard S, Cowman S, Ramasundaram R, Seed PT, O'Sullivan G. Does adding milk to tea delay gastric emptying? British Journal of Anaesthesia 2014;112(1):66-71.

34. Szarka LA, Camilleri M. Gastric emptying. Clinical Gastroenterology and Hepatology 2009:7(8):823-7.

35. Park KS, Lee JY. Probing the Utility of Ultrasonography for Assessing Degree of Functional Dyspepsia. The Korean Journal of Gastroenterology 2015:66(2):67-9. 